DOI: 10.17707/AgricultForest.63.4.01

\author{
Velibor SPALEVIC, Dragan RADANOVIC, Goran SKATARIC, \\ Paolo BILLI, Goran BAROVIC, Milic CUROVIC, Paul SESTRAS and \\ Abdulvahed KHALEDI DARVISHAN ${ }^{1}$
}

\title{
ECOLOGICAL-ECONOMIC (ECO-ECO) MODELLING IN THE MOUNTAINOUS RIVER BASINS: IMPACT OF LAND COVER CHANGES ON SOIL EROSION
}

\begin{abstract}
SUMMARY
This research presents recently introduced approach by authors of the Ecological-Economic (Eco-Eco) modelling using the Intensity of Erosion and Outflow (IntErO) model for the assessment of soil erosion intensity and the impacts of different land covers on sediment yield. The Eco-Eco modelling approach has been applied in one of the sub-basins of the River Lim in the Northeast Montenegro: Bijeli Potok River Basin $\left(2.9 \mathrm{~km}^{2}\right)$. Land use scenarios were simulated in the model aiming to define the optimal scenario of agricultural production. The Ecological (Eco-) modeling demonstrated that the real soil loss under current conditions is $307.16 \mathrm{~m}^{3} \mathrm{yr}^{-1}$ (105.91 per $\mathrm{km}^{2}$ ). If agricultural production is intensified, introducing the seed potato production on 4.4 ha of the studied river basin, the model calculated a soil loss of $312.96 \mathrm{~m}^{3} \mathrm{yr}^{-1}$ as sediment yield (107.91 per $\mathrm{km}^{2}$ ). The negative effects (caused with the intensification of agricultural production) were decreased using the measure of afforestation balancing with the identical surface of 3 ha (from meadows to forests). The model calculated that afforestation would result in a decrease of sediment yield to $306.46 \mathrm{~m}^{3} \mathrm{yr}^{-1}$ (105.67 per $\mathrm{km}^{2}$ ). The Economic (-Eco) modeling revealed that the investment (total cost) of $€ 3,385$ per hectare is needed for the establishment of the intensive agricultural - seed potato production. Market value of the final product is calculated to be $€ 8,500$ per hectare annually (yield of 17 tons per hectare); Profit $€ 5,115$; Net profit: $€ 4,558$. As an integral part of Eco-Eco modelling, the investment for the protection of the area with afforestation (implemented through the Government measures).

Farmers should strive to get economic benefits, while respecting at the same time sustainable ecological and in this specific case: river basin - watershed

1 Velibor Spalevic (corresponding author: velibor.spalevic@gmail.com), University of Montenegro, Faculty of Philosophy, Geography, Niksic, MONTENEGRO; Dragan Radanovic, Delegation of the European Union to Montenegro, Podgorica, MONTENEGRO; Goran Skataric, University of Donja Gorica, Podgorica, MONTENEGRO; Paolo Billi, University of Tottori, International Platform for Dryland Research and Education, JAPAN; Goran Barovic, University of Montenegro, Faculty of Philosophy, Geography, Niksic, MONTENEGRO; Milic Curovic, University of Montenegro, Biotechnical Faculty, Podgorica, MONTENEGRO; Paul Sestras, University of Agricultural Science and Veterinary Medicine, Cluj-Napoca, ROMANIA; Abdulvahed Khaledi Darvishan, Watershed Management, Faculty of Natural Resources, Tarbiat Modares University, IRAN.

Key note paper, presented at the $8^{\text {th }}$ International Agriculture Symposium "AGROSYM 2017", Jahorina, 5-8 October 2017, Bosnia and Herzegovina.

Notes: The authors declare that they have no conflicts of interest. Authorship Form signed online.
\end{abstract}


management. The research results show that the application of the Eco-Eco modelling, by using the IntErO model for studying the effect of soil erosion and possible land use for intensive seed potato production in the selected River Basin provides cost effective solutions for the benefit of the local population.

Keywords: Eco-Eco modelling, IntErO model, Soil erosion, Bijeli Potok River basin, Land cover.

\section{INTRODUCTION}

Soil erosion is a geomorphic process that detaches soil particles, rock fragments, soil aggregates and organic matter from its primary location and then transports these to another location by various processes (Poesen, 2017). Soil erosion causes land degradation, water management and hydro-technical problems (Gholami et al., 2014). Mountainous watersheds are affected by natural disasters, above all erosion problems, but also floods, overflows, inundations, landslides and pollution (Tazioli et al., 2015). Soil erosion and sediment yield studies are of great interest in the Mountainous areas, because of their effects on soil thickness and fertility, plant cover, runoff coefficient and flood risk. The problem of soil loss and land degradation, with their huge impact on the environment is a key point for agriculture, ecology, hydrology and hydrogeology studies (Khaledi Darvishan et al., 2017).

Study of soil erosion and sediment yield in the watershed is one of the basic necessities to achieve integrated land management and soil and water conservation (Khaledi Darvishan et al., 2016). Quantification of soil erosion in a watershed is important and one of the basic steps of all studies to encompass lots of environmental problems and to evaluate the amount of sediment moved, transported and deposited in and out of the basin. On the other hand, direct measurements of erosion in a watershed are possible with multi-years measurement of solid transport in the closing-section (Tazioli, 2009).

Sediment load measurements are useful to calibrate soil erosion models (Spalevic, 2011; Sadeghi et al., 2013; Sadeghi et al., 2014; Vujacic et al., 2017) that are after useful tools to evaluate the amount of discharge and erosion in a watershed, especially when hydrometric and discharge data are not available (Behzadfar et al., 2014).

Evaluation of the applicability of soil erosion models to a watershed is not easy, as it is difficult to accurately measure soil erosion in the field (Rawat et al., 2011). In contrast, sediment yield models are easier to apply, because the data for these models can be measured at the watershed outlet (Kinnell, 2010).

Erosion Potential Method - EPM (Gavrilovic, 1972), was in recent times repeatedly applied all over the World (Yousefi et al., 2014) but more frequently in the watersheds of Apennine and in the Balkan Peninsula (Kostadinov et al., 2014; Milevski et al., 2008; Sekularac, 2013; Spalevic et al., 2012; Spalevic et al., 2013; Spalevic et al., 2014; Stefanovic, 2004; Tazioli, 2009; Vujacic et al., 2017; Zorn and Komac, 2008). The method is based on the factors affecting erosion in a catchment; its parameters dependent on the temperature, the mean 
annual rainfall, the soil use, the geological properties and some other features of the catchment.

The objective of the present research was ecological-economic modelling by using the IntErO computer graphic model to simulate soil erosion scenarios associated with intensive seed potato production at one of the sub-basins of the River Lim in the Northeast Montenegro: Bijeli Potok River Basin $\left(2.9 \mathrm{~km}^{2}\right)$. Various land use scenarios were simulated in the model aiming to define the optimal scenario of agricultural production, examining ecological aspects of soil erosion and economic development of areas affected by soil erosion processes as well as proposing measures to overcome these issues.

\section{MATERIAL AND METHODS}

Study area. The present study was conducted in a small sub-catchment of the river Lim that is an integral part, in terms of geomorphology and climate, of the natural entity of the Polimlje region in the north eastern part of Montenegro; mountainous, with the presence of deep incised valleys (in Limestone Mountains) but also hilly. Rivers in this region drain to the Black Sea.

The studied basin covers a surface area of $2.9 \mathrm{~km}^{2}$ encompassing the villages of Brezojevice and Nadgrad. The river Bijeli Potok flows into the Lim river just $0.5 \mathrm{~km}$ after the source of the river Lim from the Plavsko Lake; $10 \mathrm{~km}$ south of Sekular, settlement of Spalevici; $18 \mathrm{~km}$ south-east of Andrijevica, $7 \mathrm{~km}$ from Murino (Fig. 1).

The natural length of the main watercourse is $2.7 \mathrm{~km}$. The shortest distance between the fountainhead and the mouth, is $2.3 \mathrm{~km}$. The total length of the main watercourse, with tributaries of I and II class, is $7.9 \mathrm{~km}$ (Spalevic et al., 2013).

There are mild slopes around the village Brezojevice and steep slopes in the upper part of the Visitor massive. The average slope gradient in the river basin, Isr, is calculated on $47.39 \%$, indicating that in the river basin prevail very steep slopes. The average river basin altitude (Hsr), the average elevation difference of the river basin (D), the natural length of the main watercourse (Lv) and the shortest distance between the fountainhead and the mouth $(\mathrm{Lm})$ are $1589.89 \mathrm{~m}, 699.89 \mathrm{~m}, 2.69 \mathrm{~km}$, and $2.3 \mathrm{~km}$, respectively.

Fieldwork \& laboratory analysis. During the field work, using a morphometric methods, various data on intensity and forms of soil erosion, land use, and the measures taken to reduce or mitigate erosion were recorded. Different forms including the shape of the slope, the depth of the erosion base and the density of erosion rills were determined.

Satellite imagery, available from the Google Earth and Google Maps, were used to estimate standard morphometric methods (Spalevic et al., 2014) and analyse the erosion rills density and the depth of the erosion base, to measure specific lengths such as the natural length of the main watercourse, tributaries, the length of the watershed and other physical-geographical characteristics.

The research part related to geology (Zivaljevic, 1989) and soils (Fustic and Djuretic, 2000) is based on previous national geological and pedological studies, who analysed all geological formations and soils of Montenegro. 

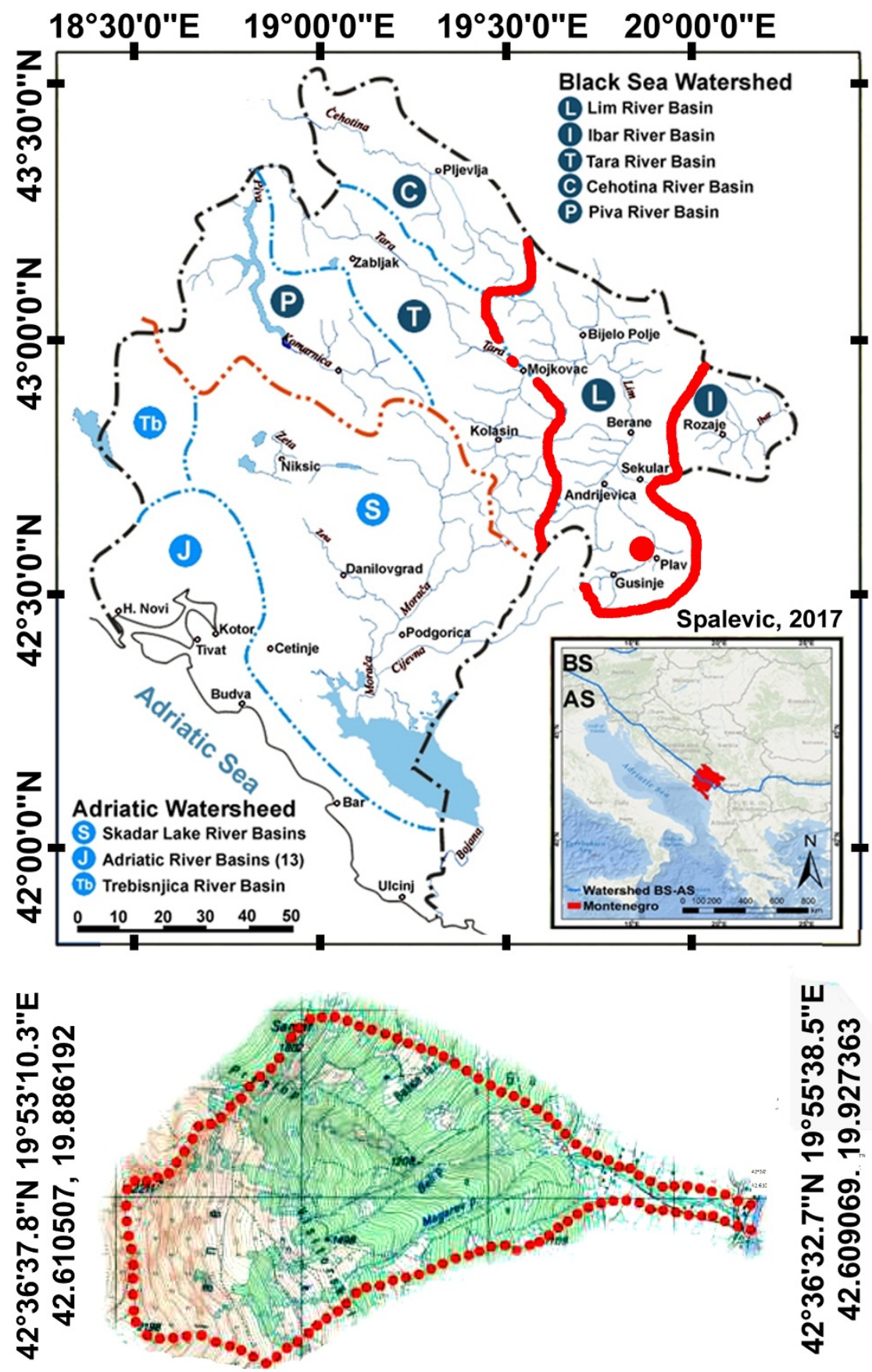

Figure 1. Location of the study area of Bijeli Potok

Polimlje: 43.245703 N, 19.580383 E (North); 42.508046 N, 19.905853 E (South); 43.148092 N, 19.485626 E (West); 42.963960 N, 20.120087 E (East). 


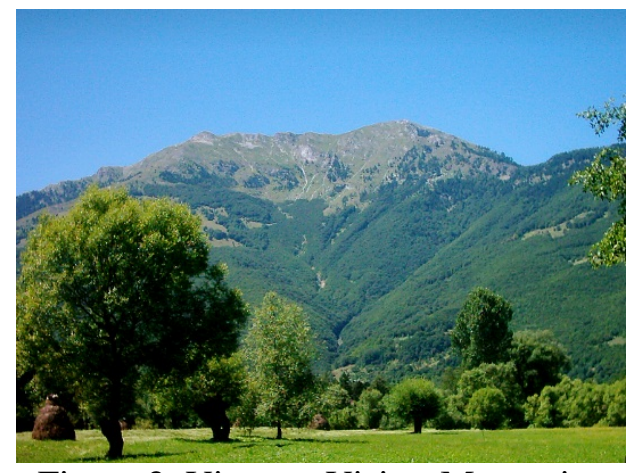

Figure 2. View on Visitor Mountain and the studied river basin

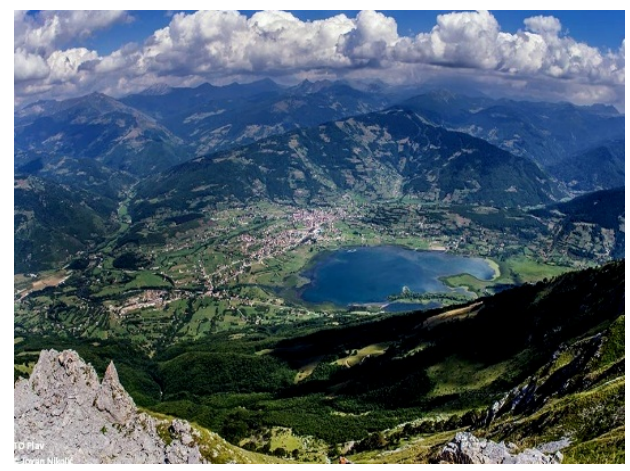

Figure 3. Plavsko Lake (907 m.asl.) from the Visitor (2211 m.asl.)

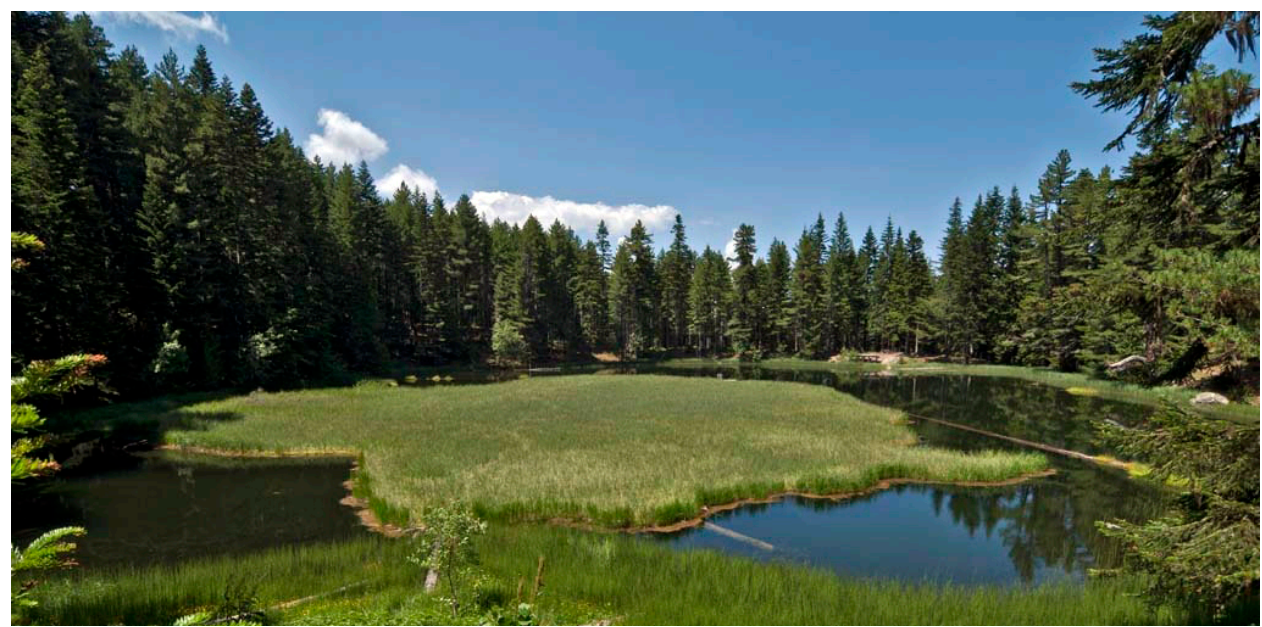

Figure 4. Visitor Lake (1.735 m.asl.; 90 x 70 m.)

north-east of the boarder of the Bijeli Potok river basin

Furthermore, some soil samples for chemical and physical analysis were collected. The grain size composition of the soil was determined by the pipette method. The soil samples were air-dried at $105^{\circ} \mathrm{C}$ sifted through $2 \mathrm{~mm}$ sieve and dispersed using sodium pyrophosphate. Total carbonates were determined by the volumetric Scheibler method; the soil reaction $(\mathrm{pH}$ in $\mathrm{H} 2 \mathrm{O}$ and $\mathrm{nKCl}$ ) was determined with a potentiometer; the content of the total organic matter was determined by the Kotzman method; easily accessible phosphorous and potassium were determined by the $\mathrm{Al}$-method and the adsorptive complex (y1, S, T, V) was determined by the Kappen method (Spalevic et al., 2017).

IntErO model application. The Intensity of Erosion and Outflow - IntErO (www.agricultforest.ac.me/Spalevic/IntErO) program package (Spalevic, 2011) was used to estimate maximum runoff discharge from the basin and the intensity of soil erosion, with the Erosion Potential Method - EPM (Gavrilovic, 1972) embedded in the algorithm of this computer-graphic method. 
The above methodology was used in Bosnia \& Herzegovina, Bulgaria, Croatia, Czech Republic, Italy, Iran, Montenegro, Macedonia, Serbia and Slovenia (Kostadinov et al., 2014). In Iran, the IntERO have been successfully used previously in the Regions of Chamgardalan; Kasilian (Amiri, 2010; Zia Abadi \& Ahmadi, 2011; Yousefi et al., 2014) and some other sub-catchments of Shirindareh River basin (Behzadfar et al., 2014 and 2015; Barovic et al., 2015; Gholami et al., 2016; Khaledi Darvishan et al., 2017).

In Italy, using the same methodology, Tazioli (2009) found that this model corresponds well concerning annual sediment yield using nuclear probes for suspended-load measurements on Musone and Esino watersheds. Similar studies were applied earlier at the Prescudin catchment in Italy, (Bemporad et al., 1997) recording a minimum deviation between predicted and measured sediment yield values (Spalevic et al., 2017).

At the Bregalnica basin in Macedonia (Milevski et al., 2008), a very good match has been achieved between the results obtained using the EPM method and onsite measurements. It should be highlighted that the EPM/IntErO model considers the total sediment load, whereas most of the measurements conducted in the studies cited take into account suspended load only.

Model verification. Sediment yields were calculated for all the tributaries of the Lim river basins, which include the Bijeli Potok river basin. The model results were then compared with the measurements obtained at the Potpec reservoir. Using the Model the sediment yield was calculated to be 347273 $\mathrm{m}^{3}$ year $^{-1}$; while actual geodetically performed measurements were 350000 $\mathrm{m}^{3}$ year $^{-1}$. This validates calculations of the results for sediment yield obtained by model. This leads to a conclusion that the model is applicable for the observed area (Spalevic et al., 2016).

\section{Model Parameters Calculation.}

Climatic characteristics. The climate is determined by the proximity of one large water area (the Lake of Plav) as well as the Prokletije and Visitor Mountains. Data used in research were provided by the Institute of Hydrometeorology of Montenegro. The studied region has a continental climate, with rainy autumns and springs and cold winters. The absolute air temperatures recorded range from a minimum of $-29.80 \mathrm{C}$ up to $35^{\circ} \mathrm{C}$. On the basis of the available data, the average annual air temperature, $\mathrm{t} 0$, is $8.1^{\circ} \mathrm{C}$; average annual precipitation is $1182.3 \mathrm{~mm}$. Calculated temperature coefficient for this area, $\mathrm{T}$, is 0.95; the torrential rain, hb, is calculated to be $89.4 \mathrm{~mm}$ (Spalevic et al., 2017).

Basic data on the area needed for the calculation of soil erosion, intensity, and runoff are presented in Tables $1-6$.

Table 1. Monthly precipitation sums in lit $/ \mathrm{m}^{2}$ - Gusinje, Montenegro

\begin{tabular}{|l|r|r|r|r|r|r|r|r|r|r|r|r|}
\hline & Jan & Feb & Mar & Apr & May & Jun & Jul & Aug & Sep & Oct & Nov & Dec \\
\hline Max & 303.7 & 270.4 & 235.3 & 258.9 & 231.4 & 162.1 & 164.5 & 165.0 & 328.9 & 552.7 & 393.2 & 398.1 \\
\hline Av & 137.9 & 119.3 & 104.5 & 127.6 & 89.1 & 73.9 & 58.6 & 66.5 & 90.8 & 138.5 & 174.9 & 163.8 \\
\hline St.d. & 104.0 & 80.0 & 54.6 & 56.7 & 46.8 & 37.4 & 39.2 & 42.7 & 67.6 & 117.3 & 91.5 & 112.3 \\
\hline
\end{tabular}


Table 2. Monthly precipitation sums in lit $/ \mathrm{m}^{2}-$ Plav, Montenegro

\begin{tabular}{|l|r|r|r|r|r|r|r|r|r|r|r|r|}
\hline & Jan & Feb & Mar & Apr & May & Jun & Jul & Aug & Sep & Oct & Nov & Dec \\
\hline max & 404.0 & 246.0 & 166.7 & 240.0 & 240.0 & 246.0 & 190.0 & 147.0 & 214.0 & 405.0 & 435.4 & 310.6 \\
\hline Av & 124.1 & 101.2 & 89.1 & 106.4 & 81.8 & 69.3 & 53.9 & 61.6 & 85.1 & 118.7 & 156.4 & 134.6 \\
\hline St.d. & 100.9 & 67.6 & 45.7 & 55.0 & 45.7 & 51.7 & 39.6 & 35.5 & 56.2 & 93.9 & 96.7 & 82.0 \\
\hline
\end{tabular}

Year $=1182.3$

Table 3. Daily Maximum in lit/m² - Plav, Montenegro

\begin{tabular}{|l|r|r|r|r|r|r|r|r|r|r|r|r|}
\hline & Jan & Feb & Mar & Apr & May & Jun & Jul & Aug & Sep & Oct & Nov & Dec \\
\hline $\max$ & 89.4 & 88.7 & 76.5 & 58.8 & 51.0 & 48.5 & 45.7 & 40.5 & 40.8 & 70.0 & 71.8 & 65.7 \\
\hline Av & 27.7 & 30.8 & 29.9 & 32.1 & 25.4 & 18.5 & 16.7 & 17.9 & 25.2 & 29.7 & 36.3 & 34.2 \\
\hline St.d. & 25.7 & 20.7 & 16.8 & 12.6 & 14.8 & 12.5 & 10.9 & 10.0 & 11.4 & 18.3 & 21.7 & 19.7 \\
\hline
\end{tabular}

Table 4. Monthly average air temperature in ${ }^{\mathrm{O}} \mathrm{C}$ - Plav, Montenegro

\begin{tabular}{|l|r|r|r|r|r|r|r|r|r|r|r|r|}
\hline & Jan & Feb & Mar & Apr & May & Jun & Jul & Aug & Sep & Oct & Nov & Dec \\
\hline $\max$ & 1.9 & 2.9 & 5.8 & 9.8 & 13.6 & 16.4 & 20.4 & 20.0 & 16.1 & 11.3 & 6.3 & 3.4 \\
\hline min & -5.2 & -4.9 & -1.9 & 6.1 & 10.4 & 13.2 & 16.0 & 15.5 & 10.4 & 7.5 & -1.3 & -3.2 \\
\hline Av & -1.4 & -0.4 & 3.2 & 7.6 & 12.4 & 15.2 & 17.4 & 17.1 & 13.4 & 9.3 & 3.2 & 0.0 \\
\hline St.d. & 2.2 & 2.2 & 2.3 & 1.1 & 1.1 & 1.0 & 1.2 & 1.3 & 1.5 & 1.2 & 2.2 & 2.0 \\
\hline
\end{tabular}

Table 5. Absolute maximum of air temperature in ${ }^{\mathrm{O}} \mathrm{C}$ - Plav, Montenegro

\begin{tabular}{|l|r|r|r|r|r|r|r|r|r|r|r|r|}
\hline & Jan & Feb & Mar & Apr & May & Jun & Jul & Aug & Sep & Oct & Nov & Dec \\
\hline $\max$ & 14.0 & 18.0 & 24.0 & 24.0 & 28.4 & 33.0 & 35.0 & 35.0 & 32.0 & 27.2 & 22.0 & 18.8 \\
\hline Av & 11.9 & 12.1 & 18.1 & 20.5 & 25.5 & 28.6 & 31.8 & 31.3 & 28.0 & 24.4 & 17.7 & 12.7 \\
\hline St.d. & 2.1 & 2.8 & 3.4 & 2.4 & 2.3 & 2.7 & 2.0 & 1.9 & 2.7 & 1.8 & 3.2 & 2.4 \\
\hline
\end{tabular}

Table 6. Absolute minimum of air temperature in ${ }^{\mathrm{O}} \mathrm{C}$ - Plav, Montenegro

\begin{tabular}{|l|r|r|r|r|r|r|r|r|r|r|r|r|}
\hline & Jan & Feb & Mar & Apr & May & Jun & Jul & Aug & Sep & Oct & Nov & Dec \\
\hline min & -29.8 & -22.2 & -18.0 & -11.2 & -1.6 & 0.0 & 0.0 & 1.0 & -1.1 & -6.4 & -17.0 & -21.0 \\
\hline Av & -16.1 & -14.1 & -9.2 & -3.1 & 0.5 & 2.3 & 4.0 & 3.7 & 2.3 & -3.1 & -9.5 & -13.6 \\
\hline St.d. & 5.2 & 3.8 & 4.8 & 2.9 & 1.4 & 1.6 & 2.0 & 1.7 & 2.1 & 2.0 & 3.5 & 4.6 \\
\hline
\end{tabular}

The amount of torrential rain, $h_{b}$, is $89.4 \mathrm{~mm}$. The average annual air temperature, $\mathrm{t}_{0}$, is $8.1^{\circ} \mathrm{C}$; average annual precipitation, $\mathrm{H}_{\text {year }}, 1345.4 \mathrm{~mm}$.

The geological structure and soil characteristics of the area. To calculate some inputs of IntErO, the geological data was extracted from the geological map of Montenegro (Zivaljevic, 1989). The area is characterised with sedimentary, magmatic and metamorphic rocks, ranging in age from Palaeozoic to Quaternary. The geological data showed that the structure of the river basin, according to bedrock permeability, is the following: poor water permeability rocks (fo), medium permeable rocks (fpp) and very permeable products from rocks (fp) 5\%, 43\% and 52\%.

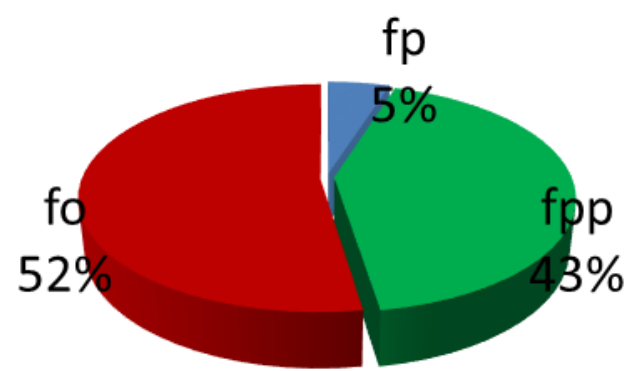

Figure 3. Permeability of the rocks 
The coefficient of the region's permeability, S1, was calculated about 0.84 .

The fact that soil properties always have an effect on the intensity of erosion has been generally accepted and confirmed by Baver (1959) and Pavicevic (1968). Those studies paid particular attention to the types of soil and their properties, with particular focus on their propensity towards erosion. Pavicevic (1956, 1957), Pavicevic and Tancic (1970), Fustic and Djuretic (2000), Antonovic (2001) and Spalevic (2011) studied the soils of the high mountains in Upper Polimlje.

Going from the inflow of the Bijeli potok past Lim to the surrounding mountainous terrain, the most common soil types are: Alluvial and AlluvialDeluvial soils, Brown Eutric soils, Brown District Soils (on Sandstones, Granite and Gneiss), Brown Soils on Limestone and Limestone and Dolomite Soils.

The structure of the river basin of Bijeli potok, according to the soil types is presented in figure 4 .

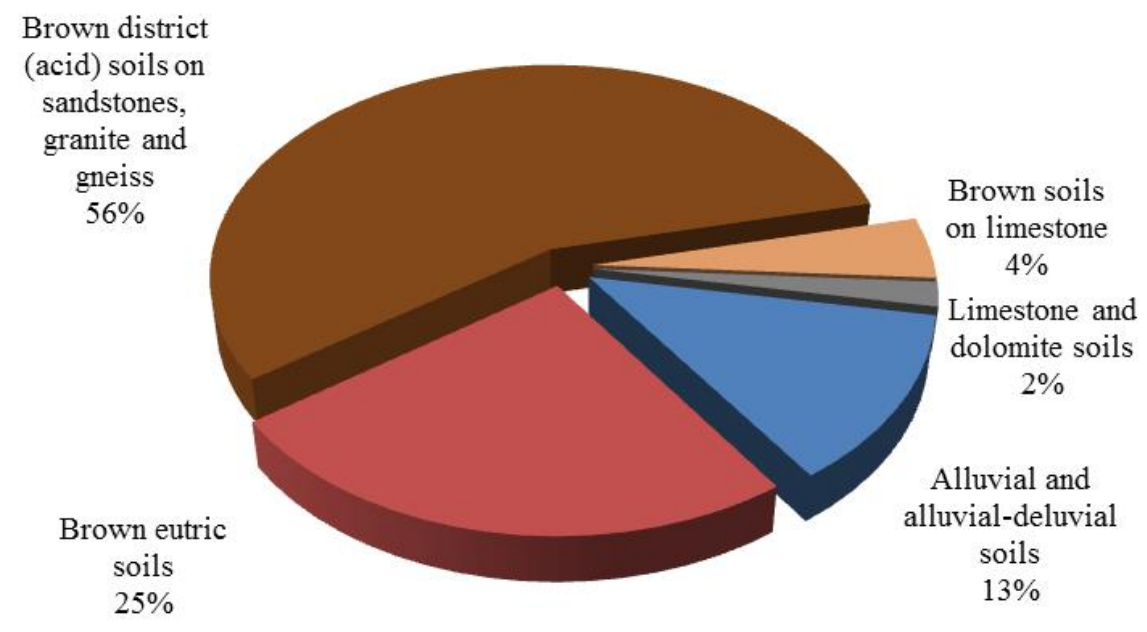

Fig. 4: The structure of Soil types in the studied river basin (Spalevic et al., 2013)

Vegetation and land use. For the purposes of calculating the maximum outflow from the river basin of Bijeli potok $\left(\mathrm{Q}_{\max }\right)$ a vegetative cover (ratio S2: part of the basin covered by forest, the grasses, orchards, as well as the barren land) was analyzed. The studied area is located in Dinaridi Province of the Middle-Southern-East European mountainous biogeographical region. The dominant type of vegetation is forests accounting for more than half of the total vegetation cover. The most important plant communities of the area are in the following classes of vegetation: Erico-pinetea, Vaccinio-picetea, Arhenanteretea, Festuco brometea, Bromion erecti, Scorzonerion villosa and Ulicionae.

On the vertical profile, according to Spalevic et al. (2013), the river basin of Bijeli potok is differentiated from the following forest communities: 
1.Fagetum montanum. Differentiated into several associations of which the most characteristic is Luzulo - Fagion moesiacae.

2.Abieti - Fagetum moesiacae Blec and Lak.

3.Picetum excelsae montanum

4.Picetum excelsae subalpinum, above $1600 \mathrm{~m}$.

5.Fagetum subalpinum between 1500-1800m (all exposures and geology)

6.Pinetum heldreichii between 1500-2000m.

7.Pinetum peuces:

a. Pinetum peuces montenegrinum Blec. between 1800-2000 m;

b. Pinetum heldreichii-peuces Lak. between 1700-2000 m;

c. Pinetum mughi above $2000 \mathrm{~m}$.

According to our analysis, the coefficient $\mathrm{f}_{\mathrm{s}}$, (part of the river basin under forests) is $0.50, \mathrm{f}_{\mathrm{t}}$ (grass, meadows, pastures and orchards) is 0.42 and $\mathrm{f}_{\mathrm{g}}$ (bare land, plough-land and ground without grass vegetation) is 0.08 .

The coefficient of the vegetation cover, $S_{2}$, is 0.71 . The coefficient of the river basin planning, $\mathrm{X}_{\mathrm{a}}$, is $\mathbf{0 . 4}$. Of the total river basin area, related to the river basin structure, well-constituted forests are the most widespread form (35\%). Further proportion is as follows: meadows (28\%), degraded forests (15\%), grassland (9\%), bare land (6\%), orchards (5\%) and arable land - plough-lands (2\%). The structure of the river basin of Bijeli Potok, according to the land use is presented in figure 5 .
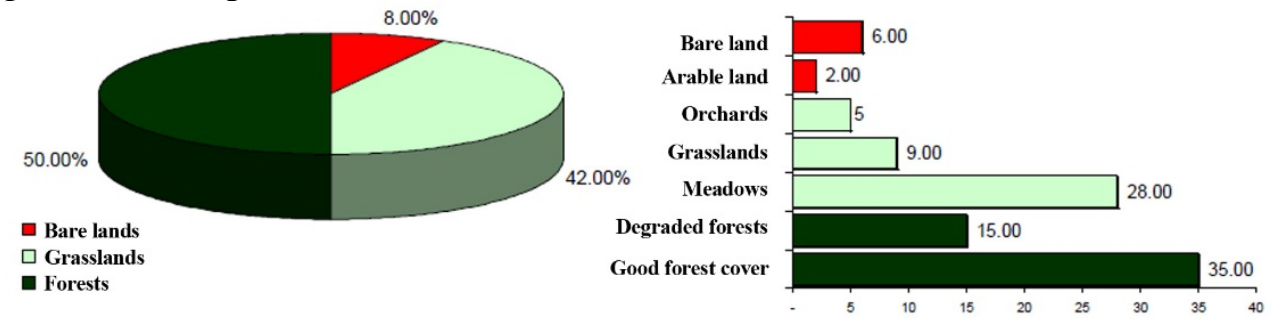

Fig. 5: Land use in the river basin of Bijeli Potok (Spalevic, 2011)

\section{RESULTS AND DISCUSSION}

Soil erosion and runoff. The relief of the hilly-mountainous terrain is characterized by steep slopes from which the water runs off and flows quickly, which is favorable for triggering the soil erosion process. The dominant erosion form in this area is surface runoff, but more severe forms of erosion, such as rills, gullies and ravines, occur also.

The erosion causes some places to lose fertile land, and results in sterile alluvial deposits on the fertile soils of the small alluvial terraces close to the main watercourse. Surface erosion has taken place in all the soils on the slopes, with the effect that this erosion is most pronounced on the steep slopes with scarce or denuded vegetation cover (Spalevic, 2011).

The software IntErO was used to process the input data required for calculation of the soil erosion intensity and the maximum outflow. 
A part of the report for the river basin of Bijeli Potok is presented in Table 7. Table 7. Part of the IntErO report (inputs and outputs) for the studied watershed

$\begin{array}{llll}\text { River basin: /08 } & 1.302132 \mathrm{~km} & 0.047 \mathrm{~km}^{2} & 0.062 \mathrm{~km}^{2} \\ \text { Input data } & 1.5839155 \mathrm{~km} & 0.056 \mathrm{~km}^{2} & 0.103 \mathrm{~km}^{2} \\ ======= & 1.560719 \mathrm{~km} & 0.072 \mathrm{~km}^{2} & 0.012 \mathrm{~km}^{2} \\ \mathrm{~F}=2.93072 \mathrm{~km} & 1.4873385 \mathrm{~km} & 0.108 \mathrm{~km}^{2} & \mathrm{~h} 0=900 \mathrm{~m} \\ \mathrm{O}=8.8377 \mathrm{~km} & 1.46047 \mathrm{~km} & 0.074 \mathrm{~km}^{2} & \mathrm{dh}=50 \mathrm{~m} \\ \mathrm{Lv}=2.6891 \mathrm{~km} & 1.3958955 \mathrm{~km} & 0.098 \mathrm{~km}^{2} & \mathrm{Hmin}=890 \mathrm{~m} \\ \mathrm{Lm}=2.30494 \mathrm{~km} & 1.351942 \mathrm{~km} & 0.087 \mathrm{~km}^{2} & \mathrm{Hmax}=2211 \mathrm{~m} \\ \text { Suma L }=7.9001 & 1.3419545 \mathrm{~km} & 0.2 \mathrm{~km}^{2} & \mathrm{fp}=0.045 \\ \mathrm{~km} & 1.2875715 \mathrm{~km} & 0.116 \mathrm{~km}^{2} & \mathrm{fpp}=0.426 \\ \mathrm{Lb}=3.73001 \mathrm{~km} & 1.209958 \mathrm{~km} & 0.12 \mathrm{~km}^{2} & \mathrm{fo}=0.527 \\ \text { Fv }=1.66941 \mathrm{~km} & 1.133764 \mathrm{~km} & 0.215 \mathrm{~km}^{2} & \mathrm{fs}=0.5026 \\ \text { Fm }=1.26131 \mathrm{~km} & 1.1002825 \mathrm{~km} & 0.144 \mathrm{~km}^{2} & \mathrm{ft}=0.422 \\ \text { Liz: } & 1.0375695 \mathrm{~km} & 0.135 \mathrm{~km}^{2} & \mathrm{fg}=0.0754 \\ 0.259726 \mathrm{~km} & 0.8958745 \mathrm{~km} & 0.195 \mathrm{~km}^{2} & \mathrm{hb}=89.4 \mathrm{~mm} \\ 0.7709245 \mathrm{~km} & 0.76636 \mathrm{~km} & 0.147 \mathrm{~km}^{2} & \mathrm{Up}=100 \text { years } \\ 0.7897265 \mathrm{~km} & 0.5009305 \mathrm{~km} & 0.16 \mathrm{~km}^{2} & \mathrm{t} 0=8.1{ }^{\circ} \mathrm{C} \\ 0.7963905 \mathrm{~km} & 0.34068 \mathrm{~km} & 0.131 \mathrm{~km}^{2} & \mathrm{H} \mathrm{yr}=1182.3 \mathrm{~mm} \\ 0.8544795 \mathrm{~km} & 0.1650615 \mathrm{~km} & 0.102 \mathrm{~km}^{2} & \mathrm{Y}=0.4 \\ 0.953394 \mathrm{~km} & \mathrm{f}: & 0.141 \mathrm{~km}^{2} & \mathrm{Xa}=0.40 \\ 1.075335 \mathrm{~km} & 0.019 \mathrm{~km}^{2} & 0.103 \mathrm{~km}^{2} & \mathrm{Fi}=0.38 \\ 1.129429 \mathrm{~km} & 0.053 \mathrm{~km}^{2} & 0.094 \mathrm{~km}^{2} & \\ 1.2246205 \mathrm{~km} & 0.061 \mathrm{~km}^{2} & 0.074 \mathrm{~km}^{2} & \end{array}$

$\begin{array}{llll}\text { Results } & \mathrm{K}=1.17 & \mathrm{~S} 1=0.84 & \mathrm{Z}=0.179 \\ \mathrm{~A}=0.64 & \mathrm{Hsr}=1589.89 \mathrm{~m} & \mathrm{~S} 2=0.71 & \mathrm{Wyr}=783.5691 \mathrm{~m} 3 \mathrm{yr}-1 \\ \mathrm{~m}=0.44 & \mathrm{D}=699.89 \mathrm{~m} & \mathrm{~W}=1.1212 \mathrm{~m} & \mathrm{Ru}=0.392 \\ \mathrm{~B}=0.79 \mathrm{~km} & \mathrm{Isr}=47.39 \% & 2 \mathrm{gDF} \wedge 1 / 2=200 \mathrm{mkm} \mathrm{s}^{-1}{ }^{1} & \\ \mathrm{a}=0.28 & \mathrm{Hleb}=1321 \mathrm{~m} & \mathrm{Qmax}=87 \mathrm{~m}^{-1} \mathrm{~s}^{-} & \mathrm{G} \mathrm{yr}=307.16 \mathrm{~m} 3 \mathrm{yr}^{-1} \\ \mathrm{G}=2.70 & \mathrm{Er}=321.37 & \mathrm{~T}=0.95 & \mathrm{G} \mathrm{yr}=104.81 \mathrm{~m}^{3} \mathrm{~km}^{-2} \mathrm{yr}^{-1}\end{array}$

Potato Production and Afforestation. In the last decades, researchers from all over the world have expressed an increased interest towards studies about economic valuation of natural well preserved areas given that environmental public goods are not always traded on a market. Economists have struggled with this subject for decades and have developed several methods to estimate the economic values of these goods, known as non-market valuation methods (Dumitras et al., 2011).

In the present research recently introduced approach by the same author's team of the Ecological-Economic (Eco-Eco) modeling was used. This approach is highlighting the message that it is possible to get economic benefits with commercial production of seed potato increasing income of farmers, improving at the same time their living standard and quality of life, while respecting at the same time sustainable watershed management.

Establishment of seed potato production. Almost all the farmers from the studied region are producing more or less vegetables for home consumption. 
Farmlands at these Mountainous altitudes (range from: Hmin, $890 \mathrm{~m}$ at the inflow of the Bijeli Potok to the Lim River; Hmax , 2211 m at Plana) are ideal for producing high quality seed potato given the clean, virus free, low disease conditions. In an environment where no fruit can be cultivated above 1,300 m asl, highland varieties of potato are an important resource for certain households in the study area, on a commercial basis. For the establishment of intensive production it is important to improve land preparation, together with fertilizers and manure usage that will increase yields by one-third (Spalevic et al., 2017).

Intensive crop production / potato production causes environmental damage by increasing the soil erosion intensities, which can be balanced by the introduction of conservation pathways. Soil erosion and its repercussion on the potato farming economic system were calculated. Calculation of seed potato production costs per 1 hectare for the region of Polimlje (Spalevic et al., 2017), where the Bijeli Potok river basin is located is presented in the Table 8.

Table 8. Calculation of seed potato production costs per hectare for the basin

\begin{tabular}{|c|c|c|}
\hline A & Production operation & Operation per ha in $€$ \\
\hline 1 & Ploughing & 100 \\
\hline 2 & Transportation of mineral fertilizers & 5 \\
\hline 3 & Distribution of mineral fertilizers & 5 \\
\hline 4 & Land Planning & 50 \\
\hline 5 & Transport of seed potatoes & 10 \\
\hline 6 & Planting potatoes & 50 \\
\hline 7 & Covering potatoes by soil & 20 \\
\hline 8 & Treatment against weeds & 10 \\
\hline 9 & Treatment of diseases and pests ( 3 times) & 30 \\
\hline 10 & Extraction of potatoes & 100 \\
\hline \multirow[t]{2}{*}{11} & Transporting the extracted potato to the warehouse & 120 \\
\hline & 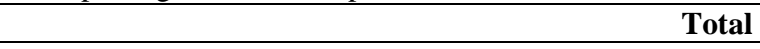 & 500 \\
\hline $\mathbf{B}$ & Raw materials & Material per ha in $€$ \\
\hline 1 & Potato seed & 1200 \\
\hline 2 & Fertilizer NPK & 500 \\
\hline 3 & Fertilizer KAN & 60 \\
\hline 4 & Herbicides & 75 \\
\hline 5 & Insecticides & 100 \\
\hline 6 & Fungicides & 160 \\
\hline 8 & Bags & 150 \\
\hline \multicolumn{2}{|r|}{ Total } & 2,245 \\
\hline $\mathrm{C}$ & Labor & Labor per ha in $€$ \\
\hline 1 & Potting of potatoes & 20 \\
\hline 2 & Loading - unloading fertilizers & 10 \\
\hline 3 & Spreading of fertilizers & 10 \\
\hline 4 & Loading - unloading of potatoes & 20 \\
\hline 5 & Seeding of potato & 40 \\
\hline 7 & Weeding weeds & 20 \\
\hline 8 & Treatment against diseases and pests & 20 \\
\hline 9 & Extraction of potatoes & 400 \\
\hline 10 & Loading - unloading of potatoes & 100 \\
\hline \multicolumn{2}{|r|}{ 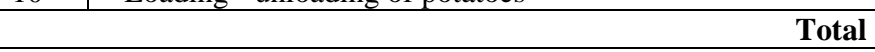 } & 640 \\
\hline & Total A+B+C & 3,385 \\
\hline
\end{tabular}




\begin{tabular}{|l|l|r|}
\hline $\mathbf{D}$ & Results & \multicolumn{1}{|c|}{ Component in $€$} \\
\hline $\mathbf{2}$ & Total cost & 3,385 \\
\hline $\mathbf{3}$ & Expected yield & $17,000 \mathrm{~kg} \mathrm{ha}^{-1}$ \\
\hline $\mathbf{4}$ & Cost of production & $0.199 € \mathrm{~kg}^{-1}$ \\
\hline $\mathbf{5}$ & Seed potato market price & $0.50 € \mathrm{~kg}^{-1}$ \\
\hline $\mathbf{6}$ & Market value of product & $8,500 €$ \\
\hline $\mathbf{7}$ & VAT (7\%) & $556.07 €$ \\
\hline $\mathbf{8}$ & Realized profit (6-2) & $5,115 €$ \\
\hline $\mathbf{9}$ & Net profit (8-7) & $4,558.93 €$ \\
\hline
\end{tabular}

Calculations arranged by the Spalevic et al. (2017) from the Table 8 under $\mathrm{A}, \mathrm{B}, \mathrm{C}$, where the total amount $(\mathrm{A}+\mathrm{B}+\mathrm{C})$ is $€ 3,385$ were challenged by the calculations of the other producers in Montenegro. The production operations costs, raw material costs and labor costs have been quantified. In agreement with Article 24 of Montenegrin VAT Law, VAT rate for seed potato is 7\%; however, in order to not over-complicate the model, the taxation issues did not examine in detail.

For this research the calculations were compared with the production of Jaksic from Zabljak (Durmitor Region, North Montenegro). The total amount realized by Jaksic from Zabljak was € 5,000 and the yield was $18.000 \mathrm{~kg} \mathrm{ha}^{-1}$, but in this case $17,000 \mathrm{~kg} \mathrm{ha}^{-1}$ was calculated. Market value of Jaksic's production was $€ 9.000$ and in the present case $€ 8,500$ was calculated. Profit of Jaksic's production was $€ 4.000$, and our calculation was $€ 5,115$. Net profit of Jaksic's production was $€ 3.400$, but our calculation shown $€ 4,558.93$ of net profit. This led us to the conclusion that our approach was appropriate for the conditions of the Mountainous region of Polimlje on the territory of Montenegro.

The area of intervention of the seed potato production is 2.93 ha, which is $1 \%$ of the 293 ha of the total river basin area. The calculated profit per hectare (see table 1d) is $€ 4,558.93$, this adds to the total profit of $€ 13,357.66$ annually for the area of intervention. This amounts to a total nominal profit of $€ 133,576.60$ for the next decade (without taking into account price changes and time value of money), which is the basic time frame for calculation of afforestation costs in this research paper (Table 9).

Calculation of afforestation costs. Calculation of afforestation costs for studied area using the local market prices and current conditions in Montenegro, have been done based on the initial research of Spalevic et al. (2017). Calculation of the afforestation costs for studied area has been presented in the table 9.

Table 9. Calculation of afforestation costs for studied area

\begin{tabular}{|l|l|r|}
\hline 1 & Type of terrain & \multicolumn{1}{|c|}{ Pasture \& barefoot } \\
\hline 2 & Conservation measure & Digging with planting \\
\hline 3 & Excavation with planting ( $€ / 8$ work. hours) & 15 \\
\hline 4 & Normative (pieces/8 working hours) & 2500 \\
\hline 5 & Number of pieces per ha & 0.18 \\
\hline 6 & Price of spruce seedlings $(€ /$ piece) & 985.71 \\
\hline 7 & Basic planting per hectare $(€)$ & 295.71 \\
\hline 8 & Filling charges for 2 years $(€)$ & $1,281.43$ \\
\hline 9 & Reforestation costs per hectare $(€)-10$ year & 128.14 \\
\hline 10 & Reforestation costs per hectare $(€)-1$ year & \\
\hline
\end{tabular}


Reforestation costs per hectare $(€)$ are $€ 128.14$ ( 1 year) and $€ 1,281.43$ (10 years). Net profit after deducting the costs of reforestation for the 10 years period (without taking into count time value of money) is $€ 133,576.6$ - $€$ $1,281.43=132,295.22$.

The reason for introduction of seed potato production is economic valuation of natural resources at the observed area. Because of the introduction of seed potato production it was necessary to balance out the increased soil erosion at the area. The essence of Eco-Eco modeling is in balancing of economic and ecological effects in dealing with the soil erosion on some selected area of land. Scenarios of land use changes are presented in the following Figure 6, Table 10.
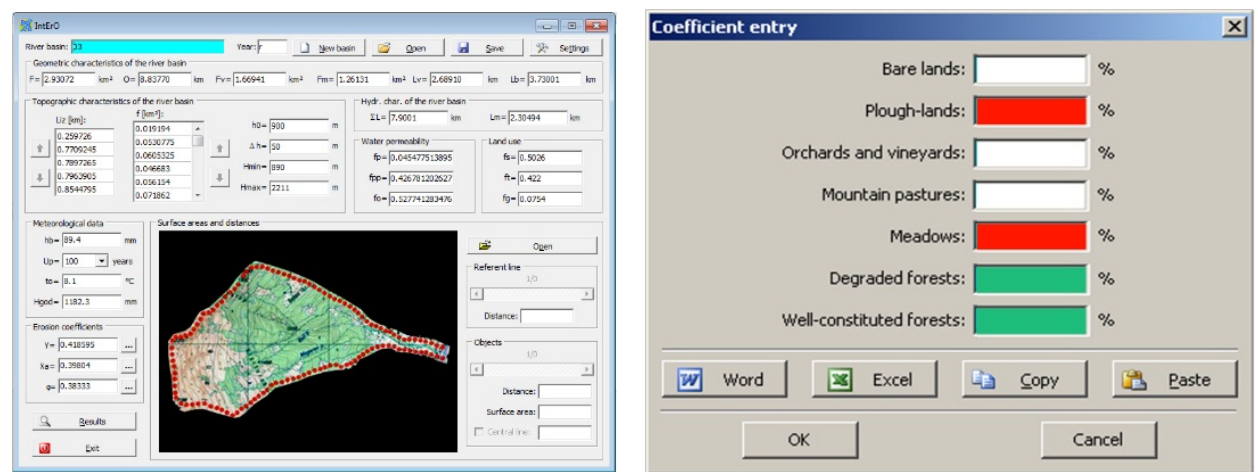

Figure 6. Form of the IntErO model including the sub-form for land use changes

Table 10. Land use changes in the Bijeli Potok river basin

\begin{tabular}{|c|c|c|c|c|c|}
\hline Land use & Symbol & Initial (1) & Potato (2) & Afforestation (3) & Units \\
\hline Bare lands: & $B L$ & 7.03 & 7.03 & 7.03 & $\%$ \\
\hline Plough-lands: & $\mathrm{P}$ & 0.50 & 1.50 & 1.50 & $\%$ \\
\hline Orchards: & 0 & 2.01 & 2.01 & 2.01 & $\%$ \\
\hline Mountain pastures: & MP & 20.10 & 20.10 & 20.10 & $\%$ \\
\hline Meadows: & $\mathrm{M}$ & 20.10 & 19.10 & 19.10 & $\%$ \\
\hline Degraded forests: & DF & 15.08 & 15.08 & 14.08 & $\%$ \\
\hline \multirow[t]{2}{*}{ Well-constituted forests } & WF & 35.18 & 35.18 & 36.18 & $\%$ \\
\hline & Suma & 100.00 & 100.00 & 100.00 & $\%$ \\
\hline Land use & Symbol & Initial (1) & Potato (2) & Afforestation (3) & Units \\
\hline Bare lands: & $\mathrm{BL}$ & 20.60 & 20.60 & 20.60 & ha \\
\hline Plough-lands: & $\mathrm{P}$ & 1.47 & 4.40 & 4.40 & ha \\
\hline Orchards: & 0 & 5.89 & 5.89 & 5.89 & ha \\
\hline Mountain pastures: & MP & 58.89 & 58.89 & 58.89 & ha \\
\hline Meadows: & $\mathrm{M}$ & 58.89 & 55.96 & 55.96 & ha \\
\hline Degraded forests: & $\mathrm{DF}$ & 44.18 & 44.18 & 41.25 & ha \\
\hline \multirow[t]{2}{*}{ Well-constituted forests } & WF & 103.08 & 103.08 & 106.01 & ha \\
\hline & Suma & 293.00 & 293.00 & 293.00 & ha \\
\hline
\end{tabular}




\begin{tabular}{|c|c|c|c|c|c|}
\hline Land use & Symbol & Initial (1) & Potato (2) & Afforestation (3) & Units \\
\hline Bare lands: & $\mathrm{BL}$ & 0.21 & 0.21 & \begin{tabular}{|r|}
0.21 \\
\end{tabular} & $\mathrm{~km} 2$ \\
\hline Plough-lands: & $\mathrm{P}$ & 0.01 & 0.04 & 0.04 & $\mathrm{~km} 2$ \\
\hline Orchards: & 0 & 0.06 & 0.06 & 0.06 & $\mathrm{~km} 2$ \\
\hline Mountain pastures: & MP & 0.59 & 0.59 & 0.59 & $\mathrm{~km} 2$ \\
\hline Meadows: & $\mathrm{M}$ & 0.59 & 0.56 & 0.56 & $\mathrm{~km} 2$ \\
\hline Degraded forests: & $\mathrm{DF}$ & 0.44 & 0.44 & 0.41 & $\mathrm{~km} 2$ \\
\hline \multirow[t]{2}{*}{ Well-constituted forests } & WF & 1.03 & 1.03 & 1.06 & $\mathrm{~km} 2$ \\
\hline & Suma & 2.93 & 2.93 & 2.93 & $\mathrm{~km} 2$ \\
\hline
\end{tabular}

The outcomes of model calculation are presented in the following Figures 7-11:

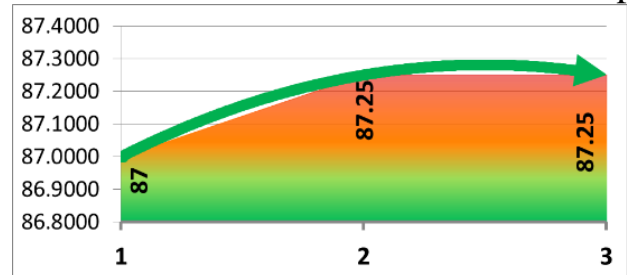

Figure 7. Coeff. of the vegetation cover

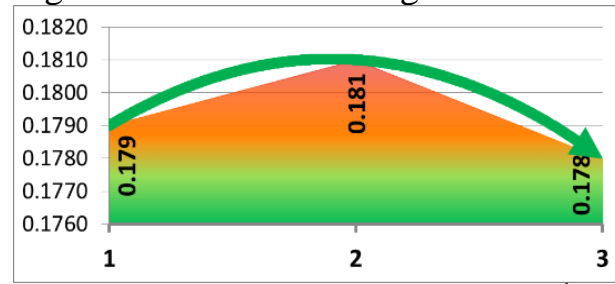

Figure 9. Erosion material $\left(\mathrm{m}^{3} \mathrm{yr}^{-1}\right)$

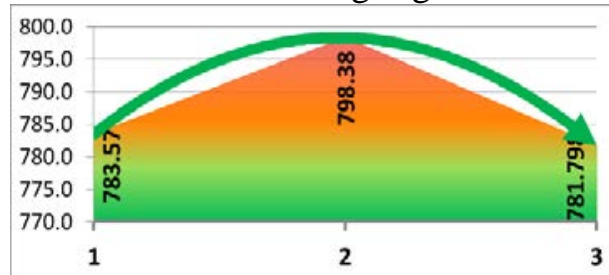

Figure 8. Peak discharge

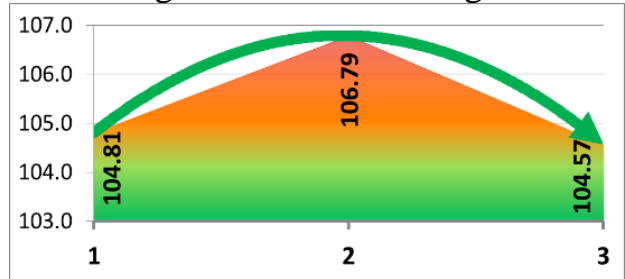

Figure 10. Erosion Coefficient Z

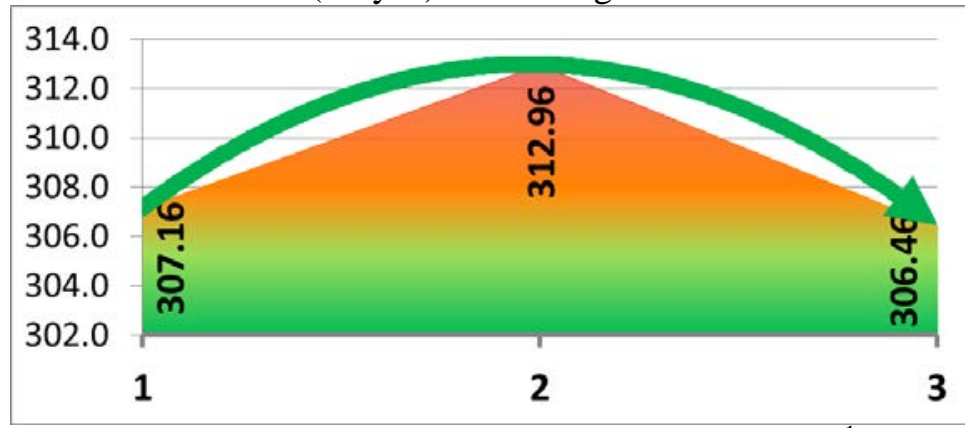

Figure 11. Real soil losses per $\mathrm{km}^{2}\left(\mathrm{G}\right.$ yr: $\left.\mathrm{m}^{3} \mathrm{yr}^{-1}\right)$

The model has taken into account all of the above parameters (27 input data and 22 results) and it was calculated that the real soil loss under current conditions is $307.16 \mathrm{~m}^{3} \mathrm{yr}^{-1}$. If seed potato production is introduced, the model calculated a soil loss of $312.96 \mathrm{~m}^{3} \mathrm{yr}^{-1}$ as sediment yield. In order to balance the damage caused by the introduction of seed potato production, the ecological measure of afforestation to reduce soil loss caused by seed potato production has been considered. The model calculated that afforestation would result in a decrease of sediment yield to $306.46 \mathrm{~m}^{3} \mathrm{yr}^{-1}$. 


\section{CONCLUSION}

Three different land use scenarios were simulated within the IntErO model in order to find the optimal scenario of land use for intensive seed potato production in the Bijeli Potok in Montenegro. It has been concluded that intensive agriculture production may be applied in conjunction with the afforestation without recording additional soil losses in the mountainous river basins.

The effects of afforestation on various variables such as soil physical, chemical and biological characteristics, water infiltration, runoff and soil loss and etc. have been already been proven in previous studies but the interaction effect between afforestation and seed potato production especially in soil loss was studied and proved again in this research at the Bijeli Potok like in a neighbouring watershed of the Velicka Rijeka.

The presented approach of Ecological-Economic (Eco-Eco) modelling using the Intensity of Erosion and Outflow (IntErO) model has potential to become a vital tool to reduce uncertainty for environmental policy decisionmaking. The team of authors is continuing the further research of this modeling which will use different type of agriculture production.

\section{REFERENCES}

Amiri, F. (2010): Estimate of Erosion and Sedimentation in Semi-arid Basin using Empirical Models of Erosion Potential within a Geographic Information System. Air, Soil and Water Research, 3: 37-44.

Barovic, G. Leandro Naves Silva, M. Veloso Gomes Batista, P. Vujacic, D. Soares Souza, W. Cesar Avanzi, J. Behzadfar M. \& Spalevic, V. (2015): Estimation of sediment yield using the IntErO model in the S1-5 Watershed of the Shirindareh River Basin, Iran. Agriculture and Forestry, 61 (3): 233-243.

Baver, L.D. (1959): Soil Physics. New York.

Behzadfar, M. Curovic, M. Simunic, I. Tanaskovik, V. \& Spalevic, V. (2015): Calculation of soil erosion intensity in the S5-2 Watershed of the Shirindareh River Basin, Iran. International Conference on Soil, Tirana, Albania; May 2015.

Behzadfar, M. Tazioli, A. Vukelic-Shutoska, M. Simunic, I. \& Spalevic, V. (2014): Calculation of sediment yield in the S1-1 Watershed, Shirindareh Watershed, Iran. Agriculture and Forestry, 60 (4): 207-216.

Fustic, B., and Djuretic, G. (2000): Soils of Montenegro. Biotechnical institute, University of Montenegro, 1-626.

Gavrilovic, S. (1972): Inzenjering o bujicnim tokovima i eroziji. Izgradnja. Beograd.

Gholami, L., Banasik, K., Sadeghi, S.H.R., Khaledi Darvishan, A. \& Hejduk, L. (2014): Effectiveness of straw mulch on infiltration, splash erosion, runoff and sediment in laboratory conditions. Journal of Water and Land Development, 22: 51-60.

Gholami, L. Batista, P.V.G. Behzadfar, A. Khaledi Darvishan, A. \& Behzadfar, M. (2016): Application of IntErO Model for Soil Loss Estimation Case Study: S7-1 Watershed of Shirindareh River Basin, Iran. Agrosym 2016: 2169-2177.

Kinnell, P.I.A. (2010): Event soil loss, runoff and the Universal Soil Loss Equation family of models: a review. Journal of Hydrology, 385: 384-397.

Kostadinov, S. Zlatic, M. Dragicevic, S. Novkovic, I. Kosanin, O. Borisavljevic, A. Lakicevic, M. \& Mladjan, D. (2014): Anthropogenic influence on erosion intensity changes in the Rasina river watershed - Central Serbia. Fresenius Environmental Bulletin, 23(1a): 254-263.

Khaledi Darvishan A., Behzadfar M., Spalevic V., Kalonde P., Ouallali A., Mouatassime E. S., (2017): Calculation of sediment yield in the S2-1 watershed of the Shirindareh river 
basin, Iran. Agriculture and Forestry, 63 (3): 23-32. DOI: 10.17707/AgricultForest.63.3.03

Khaledi Darvishan, A., Homayounfar, V., \& Sadeghi, S.H.R. (2016): The impact of standard preparation practice on the runoff and soil erosion rates under laboratory conditions, Solid Earth, 7: 1293-1302.

Milevski, I. Blinkov, I. \& Trendafilov, A. (2008): Soil erosion processes and modeling in the upper Bregalnica catchment. XXIVth Conference of the Danubian Countries. On the hydrological forecasting and hydrological bases of water management, 2-4 June 2008, Bled, Slovenia. 190 pp.

Pavicevic and Antonovic (1976): Proces erozije u slivu Lima. Arhiv za poljoprivredne nauke. Beograd.

Pavicevic and Tancic (1970): Smedja sumska zemljista u slivu Lima i sastav humusa u njemu. Arhiv za poljoprivredne nauke, No. XXIII, Sv. 82. Beograd.

Pavicevic (1968): Erozija zemljista u Sumadiji. Zbornik radova Instituta za proucavanje zemljista. Beograd.

Pavicevic (1956): Soil Erosion in the upper Lima river basin. Agriculture and Forestry, 2 (2): 1-18.

Pavicevic (1957): Osobine aluvijuma u dolini Lima. Agriculture and Forestry, 2 (1): 35-53.

Poesen, J. (2017): Soil erosion in the Anthropocene: research needs. doi: 10.1002/esp.4250

Rawat, P.K. Tiwari, P.C. Pant, C.C. Sharama, A.K. \& Pant, P.D. (2011): Modelling of stream run-off and sediment output for erosion hazard assessment in Lesser Himalaya: need for sustainable land use plan using remote sensing and GIS: a case study. Natural Hazards, 59: 1277-1297.

Sadeghi, S.H.R. Gholami, L. \& Khaledi Darvishan, A. (2013): Suitability of MUSLT for storm sediment yield prediction in Chehelgazi watershed, Iran. Hydrological Sciences Journal, 58(4): 892-897.

Sadeghi, S.H.R. Gholami, L. Khaledi Darvishan, A. \& Saeidi, P. (2014): A Review of the Application of the MUSLE Model World-Wide. Hydrological Sciences Journal, 59 (12): 365-375.

Sekularac, G. Jelic, M. Kulina, M. Jakisic, T. \& Jugovic, M. (2013): Soil erosion of the Cuverak River Basin (West Serbia). IV International Symposium, Agrosym 2013, 807810.

Spalevic, V., Lakicevic, M., Radanovic, D., Billi, P., Barovic, G., Vujacic, D., Sestras, P., Khaledi Darvishan, A. (2017): Ecological-Economic (Eco-Eco) modelling in the river basins of Mountainous regions: Impact of land cover changes on sediment yield in the Velicka Rijeka in Montenegro. Notulae Botanicae Horti Agrobotanici Cluj-Napoca, 45 (2): 602-610.

Spalevic, V., Barovic, G., Fikfak, A., Kosanovic, S., Djurovic, M., and Popovic, S. (2016): Sediment yield and Land use changes in the Northern Montenegrin Watersheds: Case study of Seocki Potok of the Polimlje Region. Journal of Environmental Protection and Ecology. 17 (3): 990-1002.

Spalevic, V. Radanovic, D. Behzadfar, M. Djekovic, V. Andjelkovic, A. \& Milosevic, N. (2014): Calculation of the sediment yield of the Trebacka Rijeka, Polimlje, Montenegro. Agriculture and Forestry, 60 (1): 259-272.

Spalevic, V. Curovic, M. Tanaskovik, V. Pivic, R. \& Djurovic, N. (2013): Estimation of soil erosion intensity and runoff in the river basin of Bijeli Potok, Northeast of Montenegro. In proceeding of the 1st International Congress on Soil Science, XIII Congress of Serbian Soil Science Society "SOIL - WATER - PLANT", October, 2013. Belgrade, Serbia.

Spalevic, V. Mahoney, W. Djurovic, N. Üzen, N. \& Curovic, M. (2012): Calculation of soil erosion intensity and maximum outflow from the Rovacki river basin, Montenegro. Agriculture and Forestry, 58 (3): 7-21.

Spalevic, V. (2011): Impact of land use on runoff and soil erosion in Polimlje. Doctoral thesis, Faculty of Agriculture of the University of Belgrade, Serbia, 260 pp. 
Stefanovic, M. Gavrilovic, Z. \& Milojevic, M. (2004): Erosion Potential method and erosion risk zoning in mountainous regions. In Internatioales Symposion IterpreventRIVAITRIENT.

Tazioli A. Mattioli A. Nanni T. \& Vivalda P.M. (2015): Natural hazard analysis in the Aspio equipped basin. Engineering geology for Society and Territory, 3, 431-435.

Tazioli, A. (2009): Evaluation of erosion in equipped basins: preliminary results of a comparison between the Gavrilovic model and direct measurements of sediment transport. Environmental Geology, 56(5), 825-831.

Vujacic, D., Barovic, G., Djekovic, V., Andjelkovic, A., Khaledi Darvishan, A., Gholami, L., Jovanovic, M. and Spalevic, V. (2017): Calculation of Sediment Yield using the "River Basin" and "Surface and Distance" Models: A Case Study of the Sheremetski Potok Watershed, Montenegro. Journal of Environmental Protection and Ecology, 18 (3): 1193-1202.

Yousefi, S., Moradi Kivarz, N., Ramezani, B., Rasoolzadeh, N., Naderi, N., Mirzaee, S. (2014): An Estimation of Sediment by Using Erosion Potential Method and Geographic Information Systems in Chamgardalan Watershed: A Case Study of Ilam Province, Iran. Geodynamics Research International Bulletin, 2 (2): 34-41.

Zia Abadi, L. \& Ahmadi, H. (2011) Comparison of EPM and geomorphology methods for erosion and sediment yield assessment in Kasilian Watershed, Mazandaran Province, Iran. Desert, 16, 103-109.

Zorn, M. \& Komac, B. (2008) Response of soil erosion to land use change with particular reference to the last 200 years (Julian Alps, Western Slovenia). XXIVth Conference of the Danubian Countries. Hydrological forecasting \& hydrological bases of water management, June 2008, Bled, Slovenia. 205 pp.

Zivaljevic M. (1989): Tumac Geoloske karte SR Crne Gore, 1:200 000; Posebna izdanja Geoloskog glasnika, Knjiga VIII, Titograd. 